\title{
Dampak Psikologis Kolonialisme Barat Terhadap Masyarakat Pribumi dalam Kumpulan Cerpen “Aloer-Aloer Merah” Karya Ardi Wina Saputra
}

\author{
Atikah Ikbar ${ }^{1)}$, Eggy Fajar Andalas ${ }^{2)}$ \\ atikahikbar31@gmail.com ${ }^{1}$, andalaseggy@gmail.com ${ }^{2)}$ \\ Program Studi Pendidikan Bahasa dan Sastra Indonesia, Universitas Muhammadiyah \\ Malang, Indonesia
}

\begin{abstract}
Abstrak. Penelitian ini bertujuan untuk mengetahui dampak-dampak kolonialisme Barat terhadap masyarakat pribumi dalam kumpulan cerpen Aloer-Aloer Merah karya Ardi Wina Saputra. Untuk mengetahui dampak mental dan dampak moral kolonialisme Barat terhadap subjek terjajah, digunakan kerangka pemikiran Edward Said. Penelitian ini menggunakan pendekatan kualitatif dengan desain deskriptif. Sumber data penelitian ini berupa kumpulan cerpen Aloer-Aloer Merah karya Ardi Wina Saputra. Teknik pengumpulan data dilakukan dengan analisis data. Analisi data dilakukan sebagai berikut, 1) Mengidentifikasi data yang diperoleh dari kumpulan cerpen Aloer-Aloer Merah karya Ardi Wina Saputra. 2) Mengklasifikasi data yang sesuai dengan Teori Poskolonialisme. 3) Menganalisis dalam bentuk deskripsi menggunakan penafsiran peneliti. 4) Menyimpulkan hasil temuan. 5) Menulis laporan hasil penelitian. Hasil penelitian menunjukkan bahwa banyak dampak moral dan mental subjek terjajah. Dampak moral subjek terjajah digambarkan dengan perilaku-perilaku masyarakat pribumi yang kehilangan identitas diri. Salah satu bentuk kehilangan identitas diri mereka adalah dengan meluapkan rasa dendamnya dan membunuh tuan-tuan Belanda. Dampak mental subjek terjajah digambarkan dengan memilih jalan kematian, yaitu bunuh diri. Bunuh diri menurutnya sebagai jalan untuk memulai dan membangun dunia baru dengan identitas baru.
\end{abstract}

Kata Kunci: psikologi, kolonialisme, cerpen

\section{Pendahuluan}

Hadirnya kolonialisme tidak hanya memberikan dampak kerusakan terhadap bangunan fisik, tetapi juga terhadap mental bangsa yang dijajah. Seperti yang disampaikan oleh Said (Andalas, 2009) Orientalisme dipahami sebagai gaya (upaya) Barat dalam mendominasi, menstruktur ulang, dan memiliki autoritas terhadap Orient. Menurutnya, melalui upaya-upaya dari berbagai bidang pengetahuan itulah yang akhirnya berdampak pada imperialisme yang tertanam dalam wacana kolonial. Said (Sugiarti, 2007) menyatakan 'imperialisme' berarti praktik, teori, dan sikap dari suatu pusat metropolitan yang menguasai wilayah yang jauh, kolonialisme yang hampir selalu merupakan konskuensi imperialisme adalah dibangunya pemukiman-pemukiman di wilayah-wilayah yang jauh. Doyle (Sugiarti, 2007) berpendapat bahwa imperialism adalah proses atau kebijaksanaan untuk menegakkan atau mempertahankan imperium. Imperium adalah hubungan, formal maupun informal, bahwa suatu negara menguasai kedaulatan politik efektif dari suatu masyarakat politik lainya. Hal ini bisa dicapai dengan paksa melalui kolaborasi poliitik, melalui ketergantungan ekonomi, dan sosial atau budaya. Dampak terbesar dari kolonialisme bukan pada bangunan fisik tetapi pada mental dan moral karena kolonialisme pada zaman sekarang tidak lagi

Atikah Ikbar ${ }^{1)}$, Eggy Fajar Andalas ${ }^{2} \mid$ Dampak Psikologis Kolonialisme Barat Terhadap Masyarakat Pribumi dalam 
menggunakan senjata tetapi menggunakan ideologi. Menurut Paxson (Saputra, 2017) terdapat dua jenis trauma yang timbul karena peperangan, yaitu trauma terhadap korban dan pelaku. Bagi korban yang terluka, disiksa, diperkosa, cacat, dipukuli, atau kaget akan tidak bisa melupakan kengerian terburuk dalam hidupnya. Sedangkan bagi pelaku entah mereka itu penembak, penyiksa, pemerkosa, dan pembunuh, dan sebagainya akan dihantui oleh ketakutan dan perasaan bersalah sepanjang hidupnya. Setiap jenis trauma akan mengubah perilaku manusia.

Permasalahan kolonialisme banyak digambarkan dalam kumpulan cerpen berjudul Aloer-Aloer Merah. Kumpulan cerpen ini banyak menggunakan seting-seting masa kolonial. Cerpen dalam antologi ini ditulis berdasarkan hasil studi dan riset terhadap kota Malang tempo dulu dan Surabaya pada masa perang sekitar tahun 1945-an dan setelahnya, di saat penjajah Jepang menyerah pada Sekutu dan kedatangan kembali tentara Belanda dengan membonceng Sekutu. Didalamnya terdapat 10 cerpen yang menggunakan seting kolonial, yaitu Aloer-Aloer Merah, Gundik, Senja Terakhir, Kutukan, Kaleng Susu, Bulan Beranak Merah Delima, Lelaki Yang Berdiri Menatap Biang Lala, Lesung Pipit, Terloepa, dan Rawis. Cerpen Bulan Beranak Merah Delima dan Terloepa memakai latar tempat Surabaya, sedangkan 8 cerpen lainnya berlatarkan tempat Malang. Alasan pengambilan latar tempat kota tersebut, karena masih dijumpai jejak arsitektur kota yang menandai tapak kekuasaan penjajah Belanda ratusan tahun silam, dan kedua kota itu menyimpan nilai historis tentang perjuangan melawan penjajahan.

Kumpulan cerpen yang berjudul Aloer-Aloer Merah, didalamya diceritakan banyak tokoh-tokoh yang mengalami dampak kolonialisme Barat. Seperti dalam kumpulan cerpen berjudul Aloer-Aloer Merahyang mewakili warna tema keseluruhan cerpen lainya rasa dendam, putus asa, dan kemarahan. Tokoh Darto membawa trauma psikologis dalam bentuk dendamnya yang begitu mendalam dengan membunuh tuan Belanda secara halus, dan menguburnya dibawah tanaman aloer karena tidak bisa menerima kenyataan bahwa ibunya dulu pernah kelelahan menanam aloer diperkosa, lalu dibunuhnya habis-habisan sepuluh tahun silam. Dendam itulah yang mendorong tokoh Darto rela bekerja menggarap ladang aloer di kali metro di kawasan bandulan Malang. Dendam sering kali membuat orang melakukan tindakan lebih kejam dari pada orang yang dianggap telah mencelakakan dirinya. Tokoh Darto sebagai subjek yang tertindas secara naluriah ingin membangun dan menunjukkan dentitasnya, sekurang-kurangnya bagi diri sendiri. Menurut Barker (Saputra, 2107) identitas menyangkut pertanyaan bagaimana kita melihat diri kita sendiri dan bagaimana orang lain melihat kita. Dalam cerpen Gundik, tokoh Suratni memilih mati meminum racun sebagai bentuk pilihan yang menunjukkan keberanianya melawan kekejaman, bukan memperlihatkan kelemahan dan kebodohannya. Kebebasan memerlukan keberanian, dan Suratni membuktikan hal tersebut. Jalan kematian menjadi pesan perdamaian yang disampaikan dengan gagah berani kepada penjajah, jalan kematian merupakan salah satu wujud dari perang dan mengandung arti melupakan masa perang yang ganas dan mengerikan, mengingat kepada manusia bahwa jalan perang merupakan jalan damai yang penuh resiko kemanusiaan, dan lupakan perang dan mulailah membangun dunia baru dengan identitas baru. Perang berkobar menyisakan penderitaan. Bukan hanya 
penderitaan fisik namun penderitaan psikologis yang berkepanjangan. Sebagian besar yang dilakukan gundik untuk membunuh tuanya adalah dengan cara mencampuri potasium, arsen atau larutan mematikan lainya. Latar belakang mereka melakukan pembunuhan secara halus tersebut adalah karena merasa kecewa dengan sikap tuanya.

Alur pengembangan cerita banyak berkisah mengenai penindasan yang dilakukan oleh tokoh-tokoh kolonial Barat terhadap masyarakat pribumi. Didalamnya banyak tokohtokoh yang merupakan masyarakat pribumi mengalami trauma-trauma psikologis. Meskipun mereka tidak berhadap-hadapan langsung dengan penjajah. Menurut Aschroft (Andalas, 2009), mengatakan bahwa penggunaan istilah poskolonial mencakup seluruh kebudayaan yang dipengaruhi oleh proses kolonialisasi mulaidari awal hingga telah dianggap tidak lagi sebagai negara kolonial. Efek-efek traumatis yang ditimbulkan melalui suara-suara bom, kebakaran, suara-suara histeris berpengaruh pada kondisi psikologis masyarakat pribumi. Permasalahan tersebut banyak digambarkan dalam kumpulan cerpen Aloer-Aloer Merah oleh karenaya penelitian ini berfokus mengenai bagaimana dampak psikologi kolonialisme Barat terhadap masyarakat pribumi dalam kumpulan cerpen Aloer-Aloer Merah. Permasalahan mental kebarat-baratan yang masih dirasakan hingga saat ini, menurut (Susanto, 2003) Pengaruh media Barat berperan besar dalam mengkontruksi pemahaman tersebut, bahwa konsumsi produk kultur Barat akan menjadi orang yang terpandang dan modern. Cenderung lebih suka menggunakan bahasa asing dari pada bahasanya sendiri, menganggap bahwa orang Barat lebih super rior dibandingkan orang pribumi, bertemu orang Barat menunduk sedangkan bertemu dengan sesama pribumi justru menampakkan gayagayanya, cenderung lebih memilih produk-produk impor karena dianggap jauh lebih baik dari pada produk dalam negeri.

Berdasarkan hal tersebut tujuan penelitian ini untuk mengetahui dampak psikologis kolonialisme Barat terhadap masyarakat pribumi yang digambarkan dalam kampulan cerpen Aloer-aloer merah. Sejauh penelusuran penulis, kumpulan cerpen ini belum pernah diteliti sebelumnya, oleh karenanya penelitian ini masih orisinil. Untuk melakukan hal tersebut maka, peneliti menggunakan teori poskolonialisme untuk menjawab tujuan mengenai dampak-dampak psikologis kolonialisme Barat terhadap masyarakat pribumi dalam kumpulan cerpen Aloer-aloer Merah.

\section{Metode}

Penelitian ini merupakan jenis penelitian kualitatif. Jenis penelitian kualitatif adalah jenis penelitian yang secara menyeluruh menggunakan cara-cara penafsiran dengan mengkaji dalam bentuk deskriptif (Ratna, 2011). Pendekatan yang digunakan adalah pendekatan poskolonialisme, khususnya pada dampak-dampak psikologis kolonialisme Barat.

Sumber dari penelitian ini berupa Kumpulan Cerpen Aloer-aloer Merah karya Ardi Wina Saputra. Data penelitian diambil dari membaca seluruh cerpen. Data penelitian ini berupa teks yang data tersebut merupakan cetakan pertama dengan sepuluh judul, dari sepuluh judul tersebut terdapat delapan cerpen yang menggunakan seting Kota Malang dan dua cerpen tersebut menggunakan seting Kota Surabaya. Sumber data yang telah diterbitkan oleh Pelangi Sastra pada tahun 2017 dengan jumlah halaman 126. Sumber data

Atikah Ikbar ${ }^{1)}$, Eggy Fajar Andalas ${ }^{2} \mid$ Dampak Psikologis Kolonialisme Barat Terhadap Masyarakat Pribumi dalam 
memperlihatkan permasalahan pada kumpulan cerpen tersebut. Permasalahan yang diperlihatkan berupa bentuk dampak-dampak psikologis Barat terhadap masyarakat pribumi yang diceritakan dalam kumpulan cerpen tersebut.

Teknik pengumpulan data yang dilakukan diperoleh dari beberapa langkah yaitu: Pertama, membaca keseluruhan kumpulan cerpen Aloer-Aloer Merah karya Ardi Wina Saputra. Kedua, memahami setiap isi cerita dari kumpulan cerpen tersebut. Ketiga, mengidentifikasi permasalahan yang menonjol dalam kumpulan cerpen tersebut. Kelima, menandai dan mencatatat objek penelitian yang terdapat dalam isi cerita. Keenam, mengklasifikasi data yang berhubungan dengan dampak psikologi Barat terhadap masyarakat pribumi.

Penelitian ini menggunakan instrumen panduan analisis. Rumusan masalah berupa masalah yang diteliti, sub masalah berisi sub-bab dalam rumusan masalah, data berupa kutipan data, data yang berasal dari kumpulan cerpen yang diteliti, dan interpretasi merupakan menafsiran peneliti terhadap data yang ditemukan. Instrumen panduan data ini sebagai alat mempermudah menjawab permasalahan penelitian. Menurut (Arikunto, 2017) data merupakan penggambaran variable yang diteliti dan berfungsi sebagai alat pembuktian hipotesis, benar tidaknya data tergantung dari baik instrumen pengumpulan data

Teknik analisis data yang digunakan dalam Kumpulan Cerpen Aloer-Aloer Merah meliputi, Pertama mengidentifikasi data yang diperoleh dari Kumpulan Cerpen Aloer-Aloer Merahkarya ardi wina saputra, kedua mengklasifikasi data yang sesuai dengan Teori Poskolonialisme. Ketiga, menganalisis dalam bentuk deskripsi menggunakan penafsiran peneliti. Keempat menyimpulkan hasil temuan. Kelima menulis laporan hasil penelitian.

\section{Hasil dan Pembahasan}

Orientalisme dalam kerangka kerja Said (Andalas, 2009) dipahami sebagai gaya (upaya) Barat dalam mendominasi, menstruktur ulang, dan memiliki autoritas terhadap orient. Menurutnya, melalui upaya-upaya dari berbagai bidang pengetahuan itulah yang akhirnya berdampak pada imperialisme yang tertanam dalam wacana kolonial. Bentuk imperialisme digunakan sebagai media yang penting dalam menciptakan subjek terjajah. Tindakan kejam itu sebenarnya merupakan komponensasi dari kegagalan manusia memperoleh identitasnya karena kekuatan kekuasaan di luar dirinya. Identitas dan subjek tidak bisa dipisahkan satu dengan yang lain. Berikut merupakan data-data yang menunjukkan adanya dampak psikologis kolonialisme Barat terhadap masyarakat pribumi, yaitu dampak pada mental dan moral pada kumpulan cerpen Aloer-Aloer Merah :

\section{Dampak Kolonialisme terhadap Mental Subjek Terjajah}

Mental berasal dari kata latin mens, mentis yang berarti jiwa, nyawa, sukma, roh, dan semangat. Menurut Drajat (Mahfud, 2014), untuk mengetahui mental seseorang apakah terganggu atau tidak bukanlah hal yang mudah, sebab tidak mudah diukur, diperiksa ataupun dideteksi dengan alat-alat ukur seperti halnya dengan kesehatan jasmani atau badan. Dampak psikologi kolonialisme Barat terhadap masyarakat pribumi menimbulkan trauma-trauma yang abadi dirasakan, dan dendam yang begitu mendalam. Berikut data-data yang

Atikah Ikbar ${ }^{1)}$, Eggy Fajar Andalas ${ }^{2} \mid$ Dampak Psikologis Kolonialisme Barat Terhadap Masyarakat Pribumi dalam 
menunjukkan adanya dampak psikologis pada mental pada kumpulan cerpen Aloer-Aloer Merah:

Mataku semakin lama semakin memerah. Darah serasa mengalir ke puncak ubun-ubun. Saat itu tiada sepatah kata pun yang terucap. !"(Bab Aloer-aloer Merah, hal 7)

"Silahkan tuan maju dan memotretnya, satu petak ini aloernya merah semua” kata-kataku meyakinkan!”(Bab Aloer-aloer Merah, hal 8)

"Hai budak!” (Bab Aloer-aloer merah, hal 8)

“arghhhhhhhhhhhhh!” (Bab Aloer-aloer Merah, hal 9)

“arghhhhhhhhh!'”(Bab Kutukan, hal 46)

Sebenarnya Roflet bukan korban pertamaku. Beberapa kompeni lain yang lewat atau melakukan sidak, juga kuhabisi dengan cara yang sama. Kemudian jasadnya kupendam dan kutanam kembali aloer-aloer itu diatasnya. !"(Bab Aloer-aloer Merah, hal 9)

"Tuan saya mohon, jangan bawa dia, Tuan, dia masih kecil, sungguh saya mohon Tuan." (Bab Gundik, hal 13)

Perlahan kutengok wajahnya! Air itu nampaknya keluar dari mulutnya yang mulai berbusa! (Bab Gundik, hal 20)

Pada kutipan data yang pertama, digambarkan tokoh pribumi yang mulai memuncak rasa emosinya. Namun, selain memuncak rasa emosinya, tokoh Darto juga melakukan gerakgerik dan maksud lain untuk membunuh Roflet, karena dendam yang begitu mendalam.

Data kedua, tokoh Darto mulai membentuk jarak dan posisi yang strategis. Membentuk jarak dan posisi yang strategis sebelum ia meluapkan emosinya merupakan faktor yang sangat penting bagi tokoh Darto. Keberhasilan membunuh Roflet, juga diperlukan membentuk jarak dan posisi yang tepat, dengan cara yang sedemikian rupa, sehingga Roflet akan berada pada posisi lebih depan dari pada tokoh Darto. Memudahkan tokoh Darto untuk membunuh dengan menusuk bambu runcingnya kepada Roflet dari belakang.

Data ketiga, Roflet memanggil Darto dengan sebutan jongos dan budak. Sebutan itu bukan saja didengarkan sekarang, namun sejak puluhan tahun lalu. Dari peristiwa-peristiwa seperti itu terbangunlah konstruksi identitas dalam Darto tertindas dan budak. Pengertian identitas menurut Barker (Marzuki, 2014) adalah soal kesamaan dan perbedaan tentang aspek personal dan sosial, tentang kesamaan individu dengan sejumlah orang dan apa yang membedakan individu dengan orang lain. Identitas seperti itu harus diruntuhkan.

Data keempat, digambarkan dengan suara parau memecah keheningan dikebun Aloer, ditutup dengan lengguhan panjang dan rintihan yang perlahan memudar sirna. Roflet telah terbujur kaku. Matanya terbuka membelak menatap keatas, mulutnya menganga dan

Atikah Ikbar ${ }^{1)}$, Eggy Fajar Andalas ${ }^{2} \mid$ Dampak Psikologis Kolonialisme Barat Terhadap Masyarakat Pribumi dalam 
kameranya remuk ditindih punggungnya yang kasar. Aloer-aloer disisi-sisinya mulai berwarna merah. Tokoh Darto telah menggalikan tanah untuk mengubur jasad Roflet disini. Tepat di tempat ibu tokoh Darto yang dulu kelelahan menanam aloer diperkosa lalu dibunuhnya habis-habisan sepuluh tahun silam.

Data kelima dari kumpulan cerpen tersebut, menunjukkan dampak mental yang dialami tokoh pribumi. Rasa dendamnya dan kecewa yang begitu mendalam, diluapkan dengan cara melakukan pembunuhan terhadap Roflet dan Louis Abelaard karena tidak bisa menerima kenyataan bahwa ibunya pernah diperkosa lalu dibunuhnya habis-habisan sepuluh tahun silam dan tokoh Leksono merasa tertindas karena harus melayani nafsu Louis Abelaard setiap malam. Dengan membunuh penciptakan identitas, menurut Hall (Hawa, dkk, 2017) memaparkan dua jenis konsep identitas, yaitu konsep esensialisme dan antiesensialisme. Konsep pertama merupakan pandangan bahwa identitas merupakan sesuatu yang terberi, tunggal, dan sama. Konsep ini tidak mengakui perbedaan sehingga membentuk hubungan oposisi biner yang direpresentasikan oleh diri dan liyan, subjek dan objek, penjajahan dan terjajah. Hal ini kemudian dijadikan pedoman bagi kaum penjajah untuk meletakkan posisinya ditengah-tengah masyarakat dan me-liyan-kan posisi kaum terjajah. Konsep kedua merupakan pandangan yang menganggap identitas adalah konstruksi yang diwacanakan melalui bahasa atau disebut sebagai antiesensialisme. Dalam pandangan antiesensialisme, identitas dipandang sebagai praktik pemaknaan melaluli bahasa yang diciptakan dan tidak terlepas dari kepentingan kekuasaan pihak tertentu. kemudian membangun identitas barunya. Dengan membunuh Roflet dan Louis Abelaard merasakan kemenangan, kebebasan, dan ketentraman hati. Dalam kondisi itu tokoh Darto melangkah untuk membangun identitas baru.

Data keenam, tokoh Darto dalam kumpulan cerpen Aloer-Aloer Merah sebagai subjek yang tertindas secara naluriah ingin membangun dan menunjukkan identitasnya, sekurang-kurangnya bagi dirinya sendiri. Menurut Barker (dalam Hawa dkk, 2017) diri merupakan subjek yang terus-menerus terbentuk dan dibentuk. Artinya, Diri dibentuk melalui hubungan saling ketergantungan terhadapa Liyan, dan dalam hal ini, perbedaan antara Diri dan Liyan menjadi samar. Subjektivitas Darto yang meliputi emosi, hasrat dan kemauan seseorang dalam melihat identitas dirinya sendiri dan pengalamanya tentang bagaimana Belanda menganggap dirinya sendiri dan pengalamanya tentang bagaimana belanda menganggap dirinya semakin memupuk rasa marahnya.

Data ketujuh, permohonan seorang tokoh pribumi yang menjadi ibu, kepada Tuan Belanda agar tidak merebut anak gadisnya. Menunjukkan bahwa tokoh tersebut sedang benar-benar dalam keadaan tertindas, karena diperlakukan Tuan Belanda dengan semenamena. Menurut Burke (Sari, 2013) relasi sosial di dalam masyarakat pada akhirnya membentuk suatu struktur sosial yang berlaku didalam masyarakat. Identitas manusia itu tidak bisa dipandang sebatas siapa dia, tetapi identitas diri hanya bisa dijelaskan melalui relasi-relasi sosial yang berada pada aktor.

Data kedelapan, tokoh gundik pada kutipan kumpulan cerpen tersebut memilih jalan kematian dengan bunuh diri, karena dari awal hidup dengan Tuan Belanda merasakan kekecewaan, pengekangan dan kekerasan Tuan-Tuan Belanda kepada para gundik. Husain

Atikah Ikbar ${ }^{1)}$, Eggy Fajar Andalas ${ }^{2} \mid$ Dampak Psikologis Kolonialisme Barat Terhadap Masyarakat Pribumi dalam 
(Mukharromah, 2014) menurut aliran human behavior, bunuh diri ialah bentuk pelarian parah dari dunia nyata, atau lari dari situasi yang tidak bisa ditolelir, atau merupakan bentuk regresi ingin kembali kepada keadaan nikmat nyaman dan tentram. Menurut Durkheim (Mukharromah, 2014) Membedakan bunuh diri menjadi empat jenis yaitu, bunuh diri egoistic, bunuh diri altruistic, bunuh diri anomi, dan bunuh diri fatalistic. Bunuh diri yang dilakukan gundik ini masuk pada tipe bunuh diri bunuh diri anomi, yaitu tipe bunuh diri yang lebih terfokus pada keadaan moral dimana individu yang bersangkutan kehilangan citacita, tujuan dan norma hidupnya.

\section{Dampak Kolonialisme terhadap Moral Subjek Terjajah}

Menurut Hurlock (Azizah,1990) moral berasal dari bahasa latin mores yang berarti tata cara, kebiasaan, perilaku, adat istiadat, dalam kehidupan. Menurut Rogers (Azizah,1977) mengartikan moral sebagai pedoman salah atau benar bagi perilaku seseorang yang ditentukan oleh masyarakat. Dampak psikologi kolonialisme barat tidak hanya pada mental saja, tetapi juga terhadap dampak pada, moral yang digambarkan pada kumpulan cerpen Aloer-Aloer Merah:

Hal pertama yang kulakukan ketika istirahat adalah membersihkan diri di kamar kecil, kubilas kaki, tangan, dan mukaku. Lalu kuambil baju yang paling bersih dan kugelar sajadah. Akupun mulai melakukan salat. Hari ini kau lebih khusyuk dari pada biasanya, ada pesan yang ingin kusampaikan pada Tuhan. Aku yakin hari ini pesan yang sama juga disampaikan oleh seluruh putra-putri bangsa di kota Malang, termasuk pak Jumarwo, lewat doa malaikat Tuhan yang ia doakan di gereja siang ini.!"(Bab senja terakhir, hal 29)

"Baik, jer, akan kujelaskan. Aku tadi membaca kitabku, namanya Al-Quran yang berarti bacaan. Tuhan pernah memerintahkan Iqra' pada Nabi Muhammad, yang berarti bacalah, oleh karena itu membaca Al-Quran aku harus membaca dengan sungguh-sungguh.!"(Bab senja terakhir, hal 30)

"Ketika diucapkan, pengaruh bunyi bahasa dalam Al-Quran itu sangat indah dan merupakan bagian terpenting dalam kitab ini," jelasku.!"(Bab senja terakhir, hal 30)

"Gerakan tersebut membuatku memantapkan sikap batin dan menetapkan arah hidupku sebagai seorang muslim. Sudah, jer, jangan mendebat lagi, aku mau melanjutkan pekerjaanku. Kau kembalilah ke asrama!" ucapku kesal.!"(Bab senja terakhir, hal 30)

Dari empat data diatas,menunjukkan sikap tokoh Sukarso pada moral bersifat religius. Menurut Daradjat (Muawanah, 2014) agama adalah proses hubungan manusia yang dirasakan terhadap sesuatu yang diyakininya, bahwa sesuatu lebih tinggi dari pada manusia. Data-data tersebut menunjukkan sikap tokoh Sukarso pada moral bersifat religius. Meskipun tokoh Sukarso bekerja di R.K Muloschool Cor Jesu, berada dalam lingkungan yang berbeda dengan keyakinan yang dianutnya, ia tetap menjalankan ritual religiusnya sama halnya

Atikah Ikbar ${ }^{1)}$, Eggy Fajar Andalas ${ }^{2} \mid$ Dampak Psikologis Kolonialisme Barat Terhadap Masyarakat Pribumi dalam 
dengan seorang muslim yang taat. Menurut Glock and Stark (Muawanah, 2014) ada lima dimensi keagamaan dalam diri manusia yaitu, dimensi praktek agama, dimensi keyakinan, dimensi pengetahuan agama, dimensi pengalaman keagamaan, dan dimensi konskuensi.

Menurut Glock dan Stark (Muawanah, 2014) religious ractice (the ritualistic dimension) yaitu tingkatan sejauh mana seseorang mengerjakan kewajiban-kewajiban ritual di dalam agamanya. Unsur yang ada di dalam dimensi ini mencakup pemujaan, kultur serta hal-hal yang lebih menunjukkan komitmen seseorang dalam agama yang dianutnya. Wujud dari dimensi ini adalah perilaku masyarakat pengikut agama tertentu dalam menjalankan ritus-ritus yang berkaitan dengan agama. Dimensi praktik dalam agama islam dapat dilakukan dengan menjalankan ibadah seperti shalat, zakat, puasa, haji dan sebagainya.

Setiap sebelum tidur, jeral selalu membancanya sembari memilin-milin bijih Rosario. Tak lupa ia sertakan doa malaikat tuhan, bapa kami, dan salam maria sebagai pelengkap baktinya.(Bab senja terakhir, hal 27)

"Bagaimana, kak? Nanti ke gereja lagi ya ya ya ?" dia kembali merengek.(Bab senja terakhir, hal 29)

Hendak kukatakan padamu bahwa perjuangan putra bangsa akan dimulai malam nanti. Hendaknya kau utus seluruh putri di asrama dan para suster untuk berdoa di gereja sore ini. Meskipun tempatnya sesak jangan kau hiraukan, yang penting semua selamat. (Bab senja terakhir, hal 31)

Angela flechen secara bergidik membaca seluruh isi surat ini. Bibirnya kaku dan kelu. Lalu ia lemas jatuh di kursinya. Segelas air putih yang tergeletak dimejanya tak kunjung disentuhnya. Matanya membelak tak percaya. Beruntung ia merupakan orang beriman, perlahan dipejamkan matanya. Tanganya menengadah diatas paha. Secara perlahan ia menarik nafas sangat dalam, lalu menghembuskanya perlahan-lahan. Sesekali memanggil nama yesus dengan berbisik pelan. Perlahan-perlahan suster sudah kembali tenang. (Bab senja terakhir, hal 32)

\section{Adikku jeral,}

Lihatlah senja telah tiba. Ingatlah engkau saat senja dulu di gereja? Saat itu senja masih teramat manis dan indah. Aku duduk menungguimu yang melaksanakan misa bersama sinyo dan noni Belanda lainya. Aku ingat ketika itu aku suntuk menunggumu di luar gereja, lalu kau datang menghampiriku dan menirukan suara ayam yang berkokok pelan, pok pok pok bunyinya dan aku tertawa mendengarnya. (Bab senja terakhir, hal 33)

Ikutilah instruksi pak Sujarwo jika kau ingijn selamat. Berdoalah di gereja dan berjaga-jaga sepanjang malam. Sebelum kembali matahari terbit esok, janganlah kau keluar gereja. Terima kasih kusampaikan padamu karena mau menemaniku saat istirahat. Capailah cita-citamu setinggi mungkin semoga kelak kita bertemu lagi. Salam, Tjokro Kirono (Sukarso) kakakmu. (Bab senja terakhir, hal 34)

Data-data di atas, sebagian diambil dari isi surat yang diberikan Sukarso kepada Suster Angela Flechen dan Jeral. Kutipan isi surat mengandung nilai moral yang

Atikah Ikbar ${ }^{1)}$, Eggy Fajar Andalas ${ }^{2} \mid$ Dampak Psikologis Kolonialisme Barat Terhadap Masyarakat Pribumi dalam 
menunjukkan ketaatan dan kepercayaan dalam beragama. Pada kutipan isi surat tersebut, banyak digambarkan bahwa ia percaya bahwa Yesus akan melindungi tempat yang dianggap mulia yaitu gereja, akan terhindar dari segala hal-hal yang tidak diinginkanya. Kristiyanto (Milla, 2007) menuliskan dalam bukunya yang berjudul "Maria dalam Gereja" demikian: “ Gereja meyakini bahwa Maria sebagai tanda harapan yang pasti serta hiburan bagi umat Allah yang berziarah". Dalam hal ini Kristianto mencoba mengangkat LGart 68 . Menurutnya, pada art 68 terkandung keyakinan gereja, bahwa melalui sosok Santa Perawan Maria gereja memperoleh gambaran tentang dirinya, yaitu gereja yang sedang dalam peziarahan di dunia dan sedang mennatikan keselamatan.

Pada kutipan data diatas juga digambarakan sosok tokoh Sukarso sangat menghargai agama yang dianut adiknya Jeral, maupun suster Angela Flechen. Rasa menghargai yang dimiliki tokoh Sukarso digambarkan ketika ia sering mengantarkan adiknya Jeral ke gereja. Selain itu, tokoh Sukarso dalam pesannya selalu mengatakan dan memerintahkan untuk berdoa meminta perlindungan kepada Tuhanya. Meskipun Sukarso beda keyakinan, nampaknya tak ada sesuatu yang mengganjal persaudaraan antara Sukarso dengan adiknya Jeral.

Profesi sebagai tukang sapu di sini sudah kumulai sejak dua tahun terakhir.

Pekerjaan ini sengaja kutekuni sebagai wujud pengabdianku pada Nusa dan Bangsa. (Bab senja terakhir, hal 27)

Profesi yang dianggap rendah oleh orang lain, namun memiliki nilai yang cukup tinggi. Pekerjaan yang diwujudkan sebagai pengabdian terhadap Nusa dan Bangsa, memiliki makna yang istimewa, karena dengan pekerjaan yang sangat sederhana itu ia wujudkan sebagai pengabdian terhadap Nusa dan Bangsa. Tokoh Sukarso bekerja sebagai tukang sapu di R.K Muloschool Cor Jesu sengaja disembunyikan kedokknya agar rekan-rekan seperjuanganya tidak ada yang menganggap sebagai londho ireng. Istilah antek-antek Belanda. Selain itu Sukarso bekerja di R.K Muloschool Cor Jesu merupakan salah satu strategi untuk mengorek informasi dari pihak Belanda.

Namun, aku sadar bahwa Sulastri tetaplah seorang manusia yang punya batas kesabaran. Batinya tidak kuat, jiwanya lemah. Tak sanggup itu semua, dia memilih mengakhiri hidupnya dengan cara tragis. Bunuh diri dengan tali sampurnya sendiri di ranjang pengantin kami. Saat itu, hanya derai air mata yang dapat kutuangkan sembari melepas jasadnya yang masih menggantung dari tali sampur yang melilit dileher.(Bab kutukan, hal 43)

Karena tidak ada jalan lain, awalnya ayahku menuruti sifat reptile Louis Abelaard itu. Kuingat setiap senja tiba, ayah pamit ke Societeit Concordia hingga pulang pagi buta dengan keadaan pucat. Lambat laun ayah menggila dan stress berat menghadapi musibah ini. Hingga akhirnya ia pulang dengan membawa nama saja karena jasadnya telah terkoyak-koyak di rel dekat Stasiun Spoor Malang. Belakangan salah satu utusan dari Staatspoorwegen mengabarkan bahwa ayah sengaja loncat ke rel kereta begitu mendengar suara kereta malam dari kejauhan. Ibu dan aku mengikhlaskan kepergian ayah, dan tidak mau mengusut kasus ini terlalu panjang. Satu hal yang pasti,

Atikah Ikbar ${ }^{1)}$, Eggy Fajar Andalas ${ }^{2} \mid$ Dampak Psikologis Kolonialisme Barat Terhadap Masyarakat Pribumi dalam 
kini ibu hidup menjanda dengan utang melilit relung jiwanya. (Bab kutukan, hal 44)

Menurut Kartono (Pratiwi, 2014) bunuh diri merupakan suatu perbuatan yang dilakukan dengan sengaja untuk mengambil jiwa sendiri. Menurut Hadriami (Pratiwi, 2014) menyatakan bahwa tindakan tindakan bunuh diri selalu didahului dengan adanya suicide ideation. Istilah suicide ideationmemacu pada pemikiran bahwa hidup ini tidak layak dijalani, mulai dari intensitas pikiran yang hanya sekilas sampai yang secara nyata dipikirkan dengan baik mengenai rencana untuk membunuh diri sendiri, atau obsesi yang lengkap dengan merusak diri sendiri. Cara tragis yang dilakukan tokoh Sulastri untuk mengakhiri hidupnya bertujuan untuk mengakhiri segala rasa yang membuat batin dan jiwanya sangat tertekan. Memendam sakit melihat kelakuan suaminya. Lewat balik pintu, dia selalu mengintip kelakuan suami dan mertuanya. Sekali dua kali Sulastri masih memaafkanya, namun Sulastri mempunyai batas kesabaran. Selain itu cara tragis, juga dilakukan oleh seorang ayah tokoh Leksono, karena tidak kuat menghadapi hutang dengan bunga yang besar sehingga membuatnay stress dan gila. Menurut Goliszek (Jannah, 2013) stress adalah suatu respon adiptif individu pada berbagai tekanan atau tuntutan eksternal dan menghasilkan berbagai gangguan, meliouti gangguan fisik, emosional, dan perilaku. Cara tragisnya dilakukan dengan cara loncat ke rel kereta dekat Stasiun Spoor Malang. Sehingga jasadnya menjadi terkoyak-koya di rel. Menurut Hawari (Jannah, 2013) menyatakan bahwa stres bisa diartikan sebagai reaksi fisik dan psikis yang berupa perasaan tidak enak, tidak nyaman atau tertekan terhadap tekanan atau tuntutan yang sedang dihadapi.

Munir dan Haryanto (Jannah, 2013) membagi stres menjadi dua bagian. Faktor eksternal, yaitu faktor yang berasal dari dalam diri seseorang. Bagaimana kondisi emosi orang yang bersangkutan dapat menimbulkan stress. Emosi adalah setiap kegiatan pergolakan pikiran, perasaan, dan nafsu. Emosi juga dapat diartikan sebagai keadaan mental seseorang. Secara umum dalam diri manusia terdapat dua emosi yang berseberangan (berlawanan), yakni positif dan negativ. Adapun kondisi-kondisi emosional yang dapat memicu munculnya stres antara lain sebagai berikut: perasaan cinta yang berlebihan, rasa takut yang berlebihan, rasa bersalah dan terkejut. Faktor eksternal. Yaitu faktor penyebab stres yang berasal dari luar diri seseorang. Dalam faktor eksternal ini dapat berupa ujian atau cobaan yang berupa kebaikan atau dianggap baik oleh manusia adalah keberhasilan, kesuksesan dalam karir dan bisnis, kekayaan yang berlimpah, kehormatan, popularitas, dan sebagainya. Macam kebaikan diatas, jika tidak disikapi dengan baik akan menimbulkan stres bagi seseorang. Berbagai persoalan dan cobaan yang menimpa kehidupan manusia yang bersifat buruk atau yang dianggap tidak baik juga merupakan faktor dan penyebab munculnya gangguan jiwa (stres) pada diri seseorang, yaitu: tertimpa musibah atau bencana alam, bahaya kelaparan dan kekeringan, kekurangan harta benda, kekurangan hasil panen, kekurangan dalam diri (cacat tubuh), problem orang tua dan sebagainya.

Kedua orang tuaku bekerja cukup giat sambil melakukan usaha apapun untuk melunasi hutang itu. Tapi sia-sia. Louis Abelaard malah menuntut ayah ke penjara. Hanya da satu cara yang dapat aku lakukan untuk melunasi hutang

Atikah Ikbar ${ }^{1)}$, Eggy Fajar Andalas ${ }^{2} \mid$ Dampak Psikologis Kolonialisme Barat Terhadap Masyarakat Pribumi dalam 
itu, yakni dengan melayani nafsu Louis Abelaard setiap malam.(Bab kutukan, hal 44)

Pada kutipan di atas digambarkan tokoh Leksono harus melayani nafsu Louis Abelaard setiap malam. Kompulsivitas seksual pada dasarnya merupakan permasalahan klinis individu. Menurut Berberovic (Rahardjo, 2016) Kompulsivitas seksual merupakan keadaan dimana individu mengalami permasalahan dalam mengendalikan pikiran, perasaan, dan perilaku seksualnya. Menurut temuan Reece dan Dodge (Rahardjo, 2016) memperlihatkan bahwa permisicvitas seksual yang muncul karena kompulsivitas seksual tersebut membuat individu terintevensi kehidupan sosialnya, termasuk penurunan tanggung jawab dan berkurangnya aktivitas keseharian. Orang tua tokoh Leksono dulu pernah bekerja pada Louis Abelaard. Mereka berdua adalah penyiar hebat di Malangsce Radio Vereeniging. Suatu ketika, tokoh Leksono mendapat kecelakaan hebat dan harus dirawat di rumah sakit. Sebagai seorang kaya raya, Louis Albelaard dengan loyalnya meminjamkan uang pada ayahnya untuk menyembuhkan tokoh Leksono. Ayahnya pun menerima dengan legawa, tapi nahas, setelah tokoh Leksono sembuh, Louis Albelaard malah menagih hutang dengan bunga yang membuat keluarga tokoh Leksono mengencangkan ikat pinggang. Kedua orang tuanya bekerja cukup giat sambil melakukan usaha apapun untuk melunasi hutang. Tetapi, semua sia-sia. Tokoh Leksono harus melayani nafsu Louis Albelaard setiap malam.

"Sayangnya aku tak bisa seperti itu, Elis. Sejak kecil aku diajarkan untuk terbiasa sabar telaten panen. Orang tuaku mengajarkan bahwa wanita haruslah halus dan lembut perkataanya. Wanita yang halus akan memiliki ketenangan. Dengan ketenangan, maka kita dapat mengendalikan keadaan di sekitar kita agar tenang dan damai. Begitu Lis." (Bab Kaleng Susu, hal 55)

Dari data di atas menunjukkan sikap orang Jawa, yang mengajarkan dan menanamkan pada anak perempuanya untuk terbiasa bersikap sabar telaten panen. Maksud dari sabar telaten panen yaitu, ketika menghadapi segala sesuatu apapun harus berlapang dada, menerima segala sesuatu dengan ikhlas dan tetap menjalani apa yang terjadi. Dengan berlapang dada akan menghasilkan panen, maksud dari panen adalah memetik hasilnya. Apapun yang terjadi dan berlapang dada maka, pasti akan menghasilkan sesuatu yang baik. Menurut Handayani dan Novianto (Triratnawati, 2005) sikap hidup orang Jawa yang mengerti etika dan taat pada adat istiadat dan serta selalu mementingkan kepentingan umum dari pada kepentingan pribadi ini harus dipraktikkan dalam pergaulan di masyarakat.

Aku melihat murid-murid berseragam putih-putih melakukan upacara bendera. (Bab Kaleng Susu, hal 52)

"Kembalikan kaleng minumku besok saat upacara ya!" (Bab Kaleng Susu, hal 59)

"MERDEKA! MERDEKA! MERDEKA!" suara itu tiba-tiba terdengar berisik keluar dari lembah (Bab Gundik, hal 15)

Atikah Ikbar ${ }^{1)}$, Eggy Fajar Andalas ${ }^{2} \mid$ Dampak Psikologis Kolonialisme Barat Terhadap Masyarakat Pribumi dalam 
"Jarik ini adalah saksi bisu pertemuanku dengan Ayahmu, Le. Coba lihat noda ini! Bekas darah dari dahi ayahmu sebelum ibu perban!” kata ibu dengan teramat mantap.

"Lho, Bu, bukankah ayah dulu tinggal di Darmo Boulevard bersama dengan keluarga besar kakek? Ah ternyata ayah selama ini ikut perang ya, Bu!" kagumku pada cerita ibu. (Bab Bulan Beranak Merah Delima, hal 62)

Nasionalisme secara politis merupakan manifestasi kesadaran Nasional yang mengandung cita-cita dan pendorong bagi suatu Bangsa, baik untuk merebut kemerdekaan atau mengenyahkan penjajahan maupun sebagai pendorong untuk membangun dirinya maupun masyarakat, Bangsa, dan negaranya. Menurut Geertz (Putri, 2018) makna upacara yaitu tetap memelihara nilai-nilai Nasionalisme dan patriotisme.

Bentuk bela terhadap Negara digambarkan dengan perang dan suara-suara semangat para pejuang di masa kolonial. Menurut Soekarno (Syarifudin, 2013: 422) mereka mengatakan bahwa rasa Nasionalisme itu menimbulkan suatu percaya diri, rasa yang perlu sekali untuk mempertahankan diri dalam perjuangan menempuh keadaan yang mau mengalahkan kita. Untuk mempertahankan diri dan negara memerlukan perjuangan yang begitu luar biasa.

\section{Simpulan}

Kumpulan cerpen Aloer-Aloer Merah berisikan dampak psikologi kolonialisme Barat terhadap masyarakat pribumi. Dampak-dampak psikogis ini banyak digambarkan pada kumpulan cerpen Aloer-Aloer Merah karya Ardi Wina Saputra. Ada dua dampak yang terdapat dalam kumpulan cerpen Aloer-Aloer Merah, yaitu dampak moral dan dampak mental. Dampak moral banyak digambarkan dengan perilaku-perilaku masyarakat pribumi yang kehilangan identitas diri. Salah satu bentuk dari kehilangan identitas diri mereka adalah dengan cara meluapkan rasa dendamnya dengan membunuh tuan-tuan Belanda. Dari peristiwa-peristiwa seperti itu terbangunlah konstruksi identitas dalam diri yang tertindas. Identitas tersebut harus diruntuhkan dengan membunuh kemudian membangun identitas barunya. Sedangkan dampak mental banyak digambarkan dengan trauma-trauma yang sulit untuk dilupakan. Dampak mentalnya digambarkan dengan memilih jalan bunuh diri. Karena memilih dengan bunuh diri atau jalan kematian mengandung arti, melupakan masa perang dan mengerikan, mengingatkan kepada manusia bahwa jalan perang merupakan jalan damai yang penuh resiko kemanusiaan, lupakanlah perang dan mulailah membangun dunia baru dengan identitas baru.

\section{Daftar Pustaka}

Andalas, E. F. (2016). Citra Antikolonial Dalam Film Avatar (2009). Sebuah Tinjauan Poskolonial. Jurnal puitika, vol. 12(1): 1-10.

Azizah, N. (2006). Perilaku Moral dan Religiusitas Siswa Berlatar Belakang Pendidikan Umum dan Agama. Jurnal Psikologi, vol. 33(2): 1-16.

Hatta, K. (2016). Trauma dan Pemulihanya. Penerbit Dakwah Ar-Raniry Press. 
Jannah, M. (2013). Bab II Landasan Teori. Dipetik dari etheses.uin-malang.ac.id Marzuki. (2014). Bab II Kajian Teoritis. 22-40.

Muawwanah, R. (2014). Bab II Kajian Teori Religiusitas. Dipetik dari etheses.uinmalang.ac.id

Pratiwi, J., \& Undarwati A. (2014). Suicide Ideation pada Ramaja di Kota Semarang, Journal Unnes, vol. 3 (1): 24-34.

Rahardjo, W. (2016). Harga Diri Seksual, Kompulsivitas Seksual, dan Perilaku Seks Berisiko pada Orang HIV/AIDS. Jurnal Psikologi, vol 43(1):52-65.

Ratna, N. K. (2014). Teori, Metode, dan Teknik Penelitian Sastra. 46-47.

Sapto, A . (2013). Perang Militer dan Masyarakat: Pemerintahan Militer pada Masa Revolusi dan Pengaruhnya pada Indonesia Kini. Sejarah dan Budaya, vol 7(1): 1833.

Saputra, A. W. (2017). Kumpulan Cerita Pendek Aloer-Aloer Merah. Penerbit Pelangi Sastra.

Saputra, A. D. (2011). Perempuan Subaltern dalam Karya Sastra Indonesia Poskolonial. Literasi, vol. 1(1): 16-30.

Sugiarti, Y. (2007). Poskolonialisme dalam Sastra dan Budaya. 3-4.

Sari, I. P. (2017). Sense Of Belong dalam Pembentukan Identitas Migran 1-8.

Tippe, S. (2013). Implemenmtasi Kebijakan Bela Negara di Perbatasan: Studi Kasus di Provinsi Papua. Journal Sosiologi, vol29(12): 416-440.

Triratnawati, Atik. (2005). Konsep Dadi Wong Menurut Pandangan Wanita Jawa. Humaniora, vol 17(3): 300-311.

Wijaya, I. S. (2016). Konstruksi Identitas Diri dalam Organisasi Etnis. Lentera, vol. XVIII(2):31-4. 